\title{
全球化与中国开发区发展的互动特征及内在机制研究
}

\section{Study on Interactive Features and Inherent Mechanisms Between Globalization and Development of China's Development Zone}

\begin{abstract}
摘要: 本文系统梳理全球化与中国开发区发展的相关性, 厘清全球化作用于中国开发 区发展的动力机制, 以及全球化背景下中国开发区规划体系的创新。进而展望在新一 轮全球化的发展进程中, 中国开发区在全球产业体系中的作用。研究发现: 中国开发 区的发展与全球化关系密切, 反映开发区全球化的外向型经济指标与开发区的总体发 展具有高度正相关性; 中国开发区发展与全球化之间存在三大互动机制与效应; 与一 般的城市规划比较, 开发区规划在适应全球化的需要、面向外向型经济发展诉求上进 行了多方面创新。面对新一轮全球化和 “一带一路” 倡议的实施, 中国的开发区模式 和开发区规划技术体系具有外向输出的客观条件和内在优势, 将成为驱动全球新一轮 工业化的新平台。
\end{abstract}

Abstract: This paper makes effort to shed light on the relevance between globalization and development zone, so as to figure out the driving force of globalization on development zone, and indicate the innovation of the system of development zone planning. Therefore, it discusses prospects of the role which development zone will play in the global industrial system with the new round of globalization. Study shows that the relationship between development of Chinese Development Zone and globalization has been so close that the export-oriented economic indicators, indicating the level of globalization, having high-positive correlation with overall development of development zone. Consequently, three aspects of interactive mechanisms and influence between the development of development zone and globalization have been argued. Furthermore, compared with general urban planning, development zone planning has been innovated in many aspects in order to meet the demands of globalization and export-oriented economic development. Facing with the new round of globalization and Belt and Road Initiative, the model of Chinese Development Zone and the technology system of development zone planning, which are considered as new platforms by taking advantage of output and inherent conditions, are the impetus driving the development of a new round of global industrialization.

关键词: 开发区; 全球化; 经济发展; 城乡规划

Keywords: Development Zone; Globalization; Economic Development; Urban and Rural Planning

国家重点研发计划战略性国际科技创新合作重点专项 “境外产业园区规划技术合作研 究与示范应用”（2016YFE0201000）资助成果

作者: 王兴平, 东南大学建筑学院, 教授, 博士生导师。wxpsx@seu.edu.cn 崔功豪, 南京大学建筑与城市规划学院, 教授

高舒欣, 东南大学建筑学院, 硕士研究生

\section{引言}

以开发区为载体推动工业化和市场经济, 是 中国改革开放取得的最为显著的成就, 也是中 国由落后、封闭的农业大国转变为开放、繁荣 的工业强国的秘诀与法宝。中国特色开发区模 式的巨大成功, 既有内力的因素, 如相对低廉 而丰富的要素成本优势、巨大的市场优势等等, 也离不开外力的驱动作用, 如国际投资、国际贸 易和国际市场等因素。其中, 全球化是中国开发 区模式形成和发展的重要外在驱动力。中国开发 区的设立顺应了全球化和国际产业转移的大潮, 其 30 多年的发展也伴随着全球化的不断深化和 拓展, 并借助全球化的力量成就了中国 “世界 工厂” 的地位。开发区作为与城市 “若即若离” 的特殊空间, 其规划与一般的城市规划具有 “和 而不同” 的关系, 面对全球化的需求, 开发区规 划在塑造 “全球化空间” 方面也发挥了重要的 支撑和引导作用, 并对中国城市规划体系的创新 提供了支撑。

当前, 伴随中国的崛起和全球竞合格局的深 刻变化, 全球化出现了新的特点, 发达国家贸易 保护主义抬头和回潮, 中国全面融入全球化和引 领全球化面临新的不确定因素。作为中国对接全 球化的最重要载体, 开发区的发展也深受影响, 需要在重新把脉全球化变化态势的基础上进行 发展模式的再创新。因此, 系统研究并科学论证 全球化与中国开发区发展之间的内在关联性及 其关联机制, 以及规划对全球化驱动下开发区发 展的支撑作用, 具有重要的学术和应用价值。 


\section{1 相关研究综述与研究设计}

海外研究者习惯将特区与城市开发区统称为 “Special Economic Zone”, 通常把中国开发区（特区）的问题置于全 球化背景下, 探讨其与全球化经济发展、区域空间结构、体 制政策的联系，并普遍认为其对区域与城市尺度下的经济增

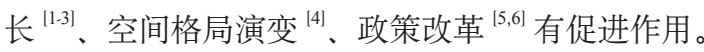

国内学者则关注各类开发区的发展、转型以及体制改革, 认为中国开发区是国家逐步开放过程中由政府主导而形成的 一种产业集聚 ${ }^{[7]}$, 初始目的是吸引外资、参与国际分工、发 展外向型经济 ${ }^{[8,9]}$ 。以影响最大、数量较多的“国家级经济 技术开发区”（简称经开区）与“国家级高新技术产业开发 区”（简称高新区）为例：经开区是应对全球经济一体化浪 潮的战略选择, 其目的是吸引国外资金和技术发展外向型经 济; 高新区是应对世界新技术革命挑战的战略选择, 其目的 是加速实现中国高新技术成果商品化、产业化和国际化 ${ }^{[10]}$ 。 因此全球化是中国各类开发区形成与转型的外动力 ${ }^{[11-14]}$, 开 发区通过增强自身竞争力适应全球化进程以促进自身发展与 转型 ${ }^{[15]}$, 包括与国际接轨的管理体制、具有国际比较优势的 产业集群以及人才资源 ${ }^{[16]}$ 。朱仲羽最早论述了开发区的功能 形态演变与经济国际化进程的同步发展关系——经济性特区 功能形态由自由贸易区到出口加工区再到科学工业园区的演 进过程, 与经济国际化从贸易领域向生产领域到高新科技领 域推进的路径基本一致 ${ }^{[17]}$ 。

一些学者对跨国公司、外商直接投资（FDI）等因素 与开发区经济发展的关系给子了特别关注。跨国公司 ${ }^{[18]}$ 、 $\mathrm{FDI}^{[19]}$ 与开发区 GDP 呈现正相关性, 目前外向型经济依然 是推动国家级开发区发展的强劲动力 ${ }^{[13]}$ 。亦有学者提出开发 区已从单纯利用外资和技术的外向窗口转变为内外资并重、 引进技术与自主创新相结合的战略支撑点 ${ }^{[20,21]}$, 应当利用地 方生产与全球网络交互作用 ${ }^{[22,23]}$, 推动开发区深层次、综合、 持续发展。同时, 在全球化的新阶段, 面向全球化、市场化 的开发区规划肩负着输出 “中国模式” 的使命 ${ }^{[24]}$ 。

总的来说, 就开发区与全球化的关系而言, 国内外学者 主要将中国开发区的问题置于全球背景下进行研究。研究成 果侧重对开发区适应全球化的发展转型进行定性分析与经验 总结, 以及对开发区总体发展与区域、城市经济增长进行定 性、定量分析, 对开发区经济发展、国际化的关系研究仍有 待补充与深化。

本文采取理论与逻辑分析、文献研究、政策分析、系统 数据分析和典型案例解析等方法, 对全球化与中国开发区发
展之间的关联性和关联互动机制、开发区规划对全球化的呼 应等进行研究, 进而展望新一轮全球化态势下中国开发区发 展与规划的动向和变革趋势。

\section{2 中国开发区发展和全球化互动的分阶段实证研究}

正如帕拉格. 康纳 (Parag Khanna) 所言, “现在遍布几 十个国家的经济特区也是自现代国家诞生以来对国家治理方 式最重大的创新, 这些经济特区不仅是本地发展之针, 也是 融人全球体系的节点” ${ }^{[25]}$, 中国的开发区也是如此。1984 年 国务院批转的《沿海部分城市座谈会纪要》是我国设立经济 技术开发区的重要文件, 文件明确提出 “经济技术开发区要 大力引进我国急需的先进技术, 集中地举办中外合资、合作、 外商独资企业和中外合作的科研机构, 发展合作生产、合作 研究设计, 开发新技术, 研制高档产品, 增加出口收汇, 向 内地提供新型材料和关键零部件, 传播新工艺、新技术和科 学的管理经验。有的经济技术开发区, 还要发展为国际转 口贸易的基地。” (1) 可以看出, 设立开发区是中国改革开放、 主动对接和承接全球经济的重要举措, 其与全球化之间天然 具有密切的联系。从 1980 年代初开发区诞生到现在, “开放、 外向” 始终是其基本与核心的政策定位。与此同时, 开发区 的使命与时俱进有所拓展, 其与全球化的互动关系和程度、 内涵也随之变化与升级。为了更为清晰、科学地判断两者的 相关性、相关度及其变化, 本文选取反映开发区全球化的相 关统计指标和开发区综合发展统计指标, 分为国家级开发区 总体情况和典型开发区个体情况两个层级, 以及经济技术开 发区和高新技术产业开发区两种类型, 建立量化分析评价模 型, 进行开发区发展与全球化互动的实证量化研究。

\section{1 开发区与全球化相关性的总体分析}

国家级开发区以经济技术开发区与高新技术产业开发区 为主, 通过对国家经开区和高新区的相关全球化和外向型经 济指标与其总体经济指标进行相关性与回归分析, 确定国家 级开发区的发展水平与全球化水平的相关性。

根据数据可得性与完整性, 选用 2002-2016 年国家级 经开区的生产总值 (GDP) 与实际利用外资额 (AUF)、进 出口总额 (TMX)、进口总额 (IMP) 、出口总额 (EXP) 数 据进行相关性分析, 分别得到相关系数为 $0.968 、 0.940 、 0.957$ 、 $0.910, p=0.000<0.01$, 皆在 0.01 水平（双侧）上显著相关。

将以上数据进行逐步回归后, 证明实际利用外资额 (AUF) 对生产总值 (GDP) 影响显著, 两者的回归分析中 线性函数模型拟合效果最好, 其回归方程为： 
$\mathrm{GDP}=-11042.403+142.408 \times \mathrm{AUF} \quad\left(\mathrm{R}^{2}=0.932, \mathrm{~F}=192.357\right)$

选用 1995-2015 年国家级高新区的营业收人 (OR)、工 业总产值 (GIP) 与出口创汇 (EX) 数据进行相关性与回归 分析, 相关系数分别为 $0.984 、 0.989, p=0.000<0.01$, 在 0.01 水平 (双侧) 上显著相关; 两者的回归分析中二次函数模型 拟合效果最好, 其回归方程为:

$\mathrm{OR}=4422.960+20.028 \times \mathrm{EX}+0.007 \times \mathrm{EX}^{2} \quad\left(\mathrm{R}^{2}=0.996\right.$, $\mathrm{F}=2$ 515.080)

$\mathrm{GIP}=3576.944+18.810 \times \mathrm{EX}+0.004 \times \mathrm{EX}^{2} \quad\left(\mathrm{R}^{2}=0.997\right.$, $\mathrm{F}=2$ 711.630)

上述结果说明, 国家级经开区的 AUR 每增加 1 亿美元 大致带来每年 142.408 亿元人民币的收人, 国家级高新区出 口创汇的增长可带来营业收人、工业生产总值的增长。两者 的检验指标 $R^{2}$ 分别为 $0.932 、 0.966$, 说明模型对样本观察值 的拟合度良好; $F$ 分别为 192.357、2 711.630, 表明模型的线 性关系显著成立。可见, 无论是国家级经开区还是高新区, 反映其全球化联系的外向型经济指标与其生产总值 (GDP) 之间存在很强的正相关关系。

此外, 为了动态分析外向型指标与经开区总体发展的内 在联系, 本文以经开区为例, 将 2002-2013 年全国所有经 开区的实际利用外资额、出口总额、进口总额数据标准化后 进行聚类分级, 完成探测因子的离散化处理。利用地理探测 器测算方法, 分别计算各探测因子对国家级经开区总体经济 发展的影响能力 P 值, 通过计算发现各因子的 P 值均在 0.6 以上, 表明 2002-2013 年全国经开区的实际使用外资、出 口总额、进口总额三项因子对经开区 GDP 表现出较高的决 定力。

\section{2 开发区与全球化关系的阶段性特征分析}

外资及其带动的外贸增长对国家级经开区积极参与全球 化进程具有阶段性作用。从指标体系来看（图 1), 2002-

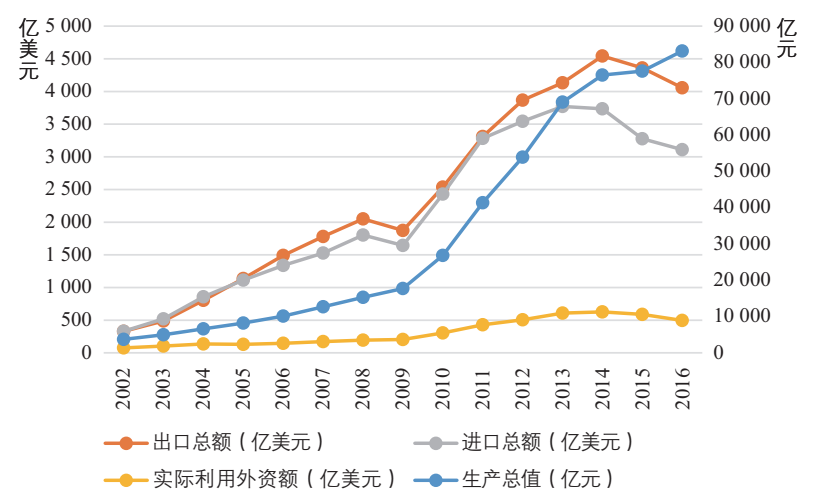

图 1 2002-2016 年国家级经开区经济指标图 资料来源 : 中国开发区统计年鉴 2003-2016，2016 年国家级经济技术开区统计年报
2005 年间进口总额比出口总额稍高, 且两者呈现增长态 势, 经开区外向型经济的逆差逐渐缩小, 实际利用外资额与 GDP 缓慢增长, 这一阶段更多的是经开区主动融人和与全 球化建立链接的阶段；2005-2009 年间实际利用外资额保 持平稳, 但进出口为顺差, 同时 GDP 增速有所提高, 这一 阶段经开区开始以产品外贸为手段, 发挥对全球化的支撑作 用；2009-2014 年间实际利用外资额保持平稳增长, 进出 口总额的顺差进一步扩大, 同时 GDP 加速增长, 说明外资 及外贸双轮驱动了经开区的发展, 经开区融人全球化的程度 进一步强化；2014 年以后, 伴随 GDP 进一步快速增长的是 进出口和外资的全面下降, 这一阶段经开区的发展动力逐步 由外向型驱动转变为内需市场驱动和园区城镇化带来的房地 产驱动。

出口创汇对国家级高新区在全球化进程中的状态同样具 有标识性作用。从相关指标变化来看（图 2), 1995-2001 年间出口创汇与营业收人均缓慢增长且增长趋势相近, 说明 此时高新区高新技术成果产品化、产业化、国际化处于相互 融人状态; $2001-2009$ 年间出口创汇迅速增长且增长速度 高于营业收人, 说明此时高新区高新技术成果的国际化水平 迅速提高, 支撑高新区的发展; 2009 年至今, 出口创汇与 营业收人增长速度接近且均保持较大增速, 说明此时高新区 出口与经济发展保持良性互动的状态。

为进一步说明问题, 本研究选取国家级杭州经济技术 开发区作为个案, 根据数据可得性, 选用其 1995-2015 年 的生产总值 (GDP) 与实际利用外资额 (AUF) 、出口总额 (EXP) 数据进行相关性分析, 分别得到相关系数为 0.951 、 $0.873, p=0.000<0.01$, 皆在 0.01 水平（双侧）上显著相关。 将以上数据建立线性回归模型：

$\mathrm{GDP}=57.901 \times \mathrm{AUF}+1.885 \times \mathrm{EXP}-51.529 \quad\left(\mathrm{R}^{2}=0.927\right.$, $\mathrm{F}=113.959$ )

$R^{2}$ 为 0.927 说明模型对样本观察值的拟合度良好; $F$ 为

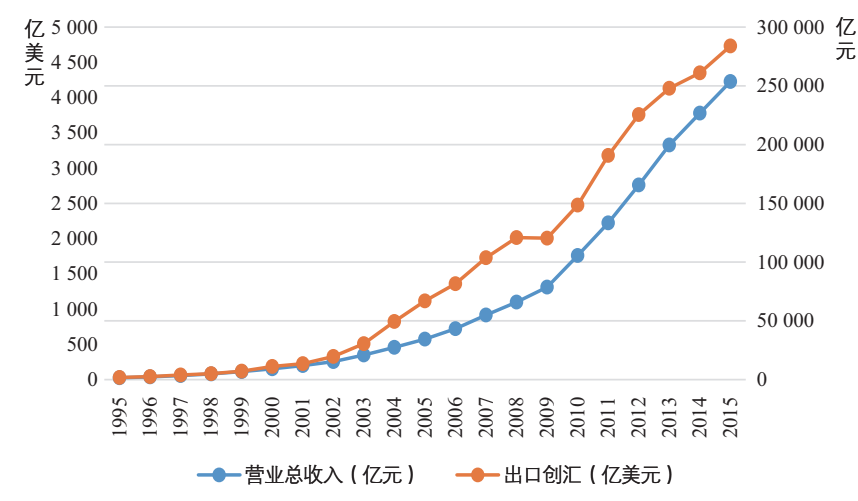

图 2 1995一2015 年高新区经济指标图 资料来源 : 中国火炬统计年鉴 2016 
113.959 表明模型的线性关系显著成立。因此可以说明, 杭 州经开区的实际利用外资额、出口总额的增长可带动生产总 值的增长。

进一步分析杭州经开区实际使用外资、出口总额以及 GDP 三者的增长关系（图 3)。1995-2002 年, 杭州经开区 实际使用外资、出口总额等外向型经济指标与 GDP 增长态 势相似，但是外资增速略高于外贸和 GDP，显示开发区处 于外资驱动发展的阶段； 2002-2009 年, 外向型经济指标中 出口总额迅速增长又大幅回落, 但是其平均增速高于实际使 用外资和 GDP 增速, 显示开发区处于外贸驱动发展的阶段; 2009 年至今, 外向型经济指标与 GDP 波动增长, 但是 GDP 增速高于外贸和外资增速, 说明开发区的经济发展逐步具备 内在动力并拉动外向型经济发展。这与前文对国家级经开区 整体分析的结论基本一致。

\section{3 中国开发区发展和全球化互动的内在机制分析}

全球化为中国开发区的发展提供了动力, 中国开发区的 发展助推了全球化的发展, 并逐步改变和重塑了国际分工、 国际贸易和国际投资体系。全球化和中国开发区的发展互为 动力, 相互促进, 成为形塑当代新的全球化格局特别是全球 工业体系的重要机制。总体来看, 全球化与中国开发区的互 动发展主要通过资本、商品和市场、人才等要素来实现, 而 国内外的相关政策和各种规制则通过调节要素流动的门槛等 影响流动成本, 进而影响流速、流向、流量等, 其基本机制 如图 4 所示。

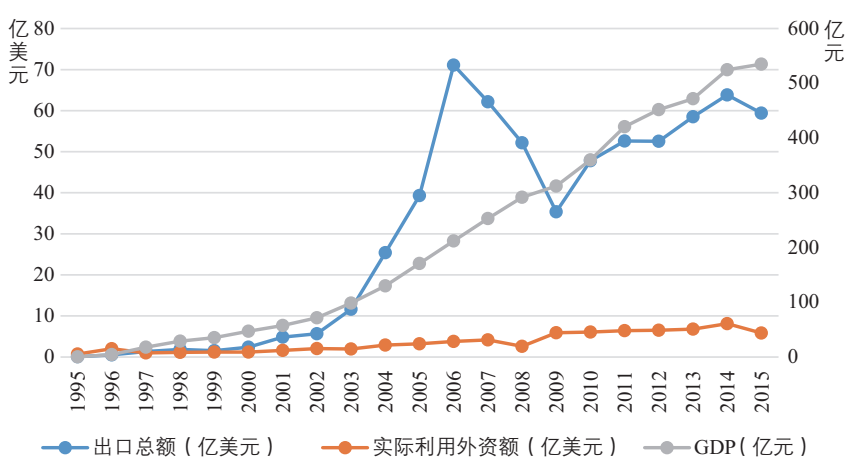

图 3 1995一2015 杭州经济开发区经济指标 资料来源 : 杭州经济技术开发区年鉴 2016
总体而言, 全球化与开发区的互动机制, 可以概括为 三个方面的作用和效应, 包括政策激励机制、要素纽带机制 以及比较优势形成的集聚机制。在政策方面, 中国改革开放 政策发挥重要的“堖杠” 作用, 打开了中国与全球化隔离的 “闸门”, 形成了中国开发区与全球化对接的“窗口”并逐 步扩展; 而世贸组织及其相关规制为中国深度融人全球化提 供了平台和保障。在要素方面, 国际投资和国际贸易带动资 本和商品在中国开发区与全球市场之间形成了循环并不断强 化, 是中国开发区与全球化互动的重要内容。在集聚机制方 面, 则是相关政策和中国本土生产要素综合形成的低成本、 高效率和宽管制优势带动形成的聚流效应。

\section{1 相关政策和国际规制的激励机制：政策闸门和窗口 效应}

1984 年出台设立经开区的文件之后, 陆续出台了一系 列相关细节性政策以应对实际操作中遇到的种种问题, 包括 直接性政策和间接性政策。直接性政策例如对开发区免征和 减征企业所得税的政策 ${ }^{1}$ 、改善外商投资环境的政策 ${ }^{2}$ 、缓 解开发区开发建设债务负担的政策 ${ }^{3}$ 、鼓励高新技术企业发 展的政策 ${ }^{(4)}$ 、优化开发区管理体制的政策 ${ }^{(5)}$ 等等; 间接性政 策包括土地使用权出让和转让的政策 ${ }^{(6)}$ 、内外资企业所得税 税率规定的政策 ${ }^{(7)}$ 等等。开发区政策逐渐从单一的 “原则规 定”变化成多元化全方位的政策体系，涉及多个部门，涵盖 税收、投融资、土地、产业发展和科技等等。除了国家层面 的政策之外, 地方政府和开发区本身也出台了不少 “特上加

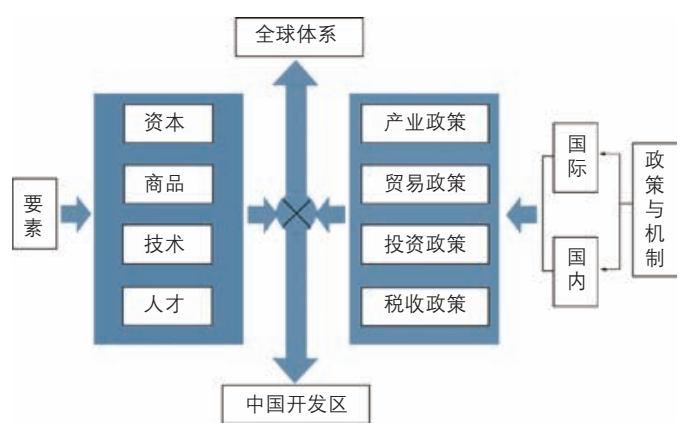

图 4 中国开发区与全球化互动机制示意图 资料来源：作者绘制

(1)《关于经济特区和沿海十四个港口城市减征、免征企业所得税和工商统一税的暂行规定》(国发 [1984]161 号)

(2)《关于鼓励外商投资的规定》(国发[1986] 第95 号) : 对经济特区、经济技术开发区内的“产品出口企业”和“先进技术企业”给予特别优惠的规定, 将其企业所得税税率降为 $10 \%$ 。

(3)《关于经济特区、经济技术开发区开发性货款实行差别利率和贴息的规定》(银发 [1987]4 号)

(4)《国务院关于批准国家高新技术产业开发区和有关政策法规的通知》(国发 [1991]12 号)

(5) 科技部关于印发《关于加速国家高新技术产业开发区发展的若千意见》的函(国科发火字 [1999]302 号)

(6)《中华人民共和国城镇国有土地使用权出让和转让暂行条例》(国令 [1990]55 号); 《国务院关于深化改革严格土地管理的决定》(国发 [2004]28 号)

７（《中华人民共和国外商投资企业和外国企业所得税法》；《中华人民共和国企业所得税暂行条例》(国令 [1993]137 号) 
特” 的政策, 增加其市场竞争的政策 “筹码”。这些开发区 起步发展期的政策总体上倾向于 “外资、外贸” 偏好, 特别 是影响巨大的 “两免三减半” 和土地优惠等政策, 降低了外 资制造业来华投资的成本, 极大促进了中国开发区迅速融人 全球化和成为全球工业投资高地。

\section{2 国际投资与国际贸易的纽带机制：资本逐利、市场 逐利效应}

中国开发区与全球化之间, 以国际投资和国际贸易为 核心纽带密切衔接在一起。开发区始终是中国吸引国际资本 的核心载体, 也以 “世界工厂” 的角色成为中国外贸产品的 重要生产基地, 并逐渐跃居为国际供应链体系的关键组成部 分。有关数据表明, 2008 年, 江苏省开发区使用外资和对 外贸易分别占全省的 $77 \%$ 和 $71 \%{ }^{1}$, 在近 10 年的发展中, 全省开发区历年进出口总额均占全省多年比重的 $70 \%$ 以上。 “十二五”末, 南京市全市开发区实现进出口、出口、进口 分别为 255.6、153.6、102 亿美元, 占全市比重分别为 48\%、 $48.7 \%$ 、 $46.9 \%$; 实际使用外资 18.3 亿美元, 占全市比重为 $54.9 \%$ 。可以看出, 开发区基本占据了全市外向型经济的 半壁江山, 是南京经济对接全球化当之无愧的排头兵和主阵 地所在。目前, 随着国内经济的转型升级, 国际技术、人才 的集聚已成为许多开发区对接全球化的新纽带, 并逐步成为 国际前沿技术产业化的转化基地, 部分开发区已经在开展高 层次要素的输出, 向引领全球化的阶段迈进。

为了明确开发区与全球投资的关系, 本文通过对苏州工 业园区、杭州经济开发区企业投资网络的研究来分析其结构 和联系特征。研究发现, 在开发区投资的企业多为国际企业 的一个重要分支或者节点, 开发区通过企业资本纽带已经与 国际生产投资网络密切地联系在一起。

根据规上工业企业的投资来源, 苏州工业园区和杭州经 开区外资引进和利用都较为显著, 主要吸引了欧美等发达国 家企业来华投资 (图 5)。苏州工业园区作为中新两国合作 园区, 新加坡企业投资相对更多, 且国外企业投资也多数为 直接投资; 而杭州经开区则吸引了更多间接投资, 即许多外 资企业通过在北京、上海等城市的中国总部在杭州经开区投 资设立子公司。同时, 随着内资企业发展壮大, 越来越多的 内资企业 “走出去” 进行海外投资设厂。杭州经开区 “三花 微通道” 的母公司 “浙江三花智能控股股份有限公司” 是进 行全球化生产布局的先行企业, 目前已在美国、墨西哥、印 度、捷克、奥地利等国设立了生产基地。

\section{3 低成本 \& 高效率、宽管制 \& 优服务的集聚机制 : 洼地效应、集聚效应}

任何时期、任何地域, 低成本 \& 高效率、宽管制 \& 优 服务是吸引投资、集聚发展要素的核心竞争力。在政策塑 造的成本洼地效应和宽管制环境、文化传统和教育优势塑 造的人力资源高地效应等综合作用下, 中国的开发区成为 全球外商投资青睐的“乐土”。其中, 低成本是开发区起步 和发展期比较看重的竞争优势, 而高效率则是开发区进人 加速发展期之后非常关注的因素。中国开发区在 2000 年以 前主要依靠低成本和宽管制形成的洼地效应来集聚国际投 资, 2000 年以后则更多地依靠高效率和优服务吸引高层次 国际要素的集聚。目前, 随着开发区综合成本的上升和综 合实力的提升, 逐步开始迈向由单纯的集聚国际要素到要 素和能力输出的新的全球化阶段。营商成本高低是国际要 素流动非常关键的指标, 依据顾惠的相关研究, 作为开发 区营商成本重要组成部分的工业用地价格一直维持在低位, 其与住宅、商服用地的价格比例由 2000 年的 1:2:4 发展为 2016 年的 $1: 8: 9$, 而且还不算地方和园区的各种进一步的 “零 地价” 甚至 “负地价” 政策 ${ }^{[26]}$ (图 6)。再加上过去低廉的 劳动力成本和税负, 以及开发区专业化机构的高效率服务 形成的低制度成本等, 加速吸引了国际制造业投资和产能 向中国开发区的流人和集聚。

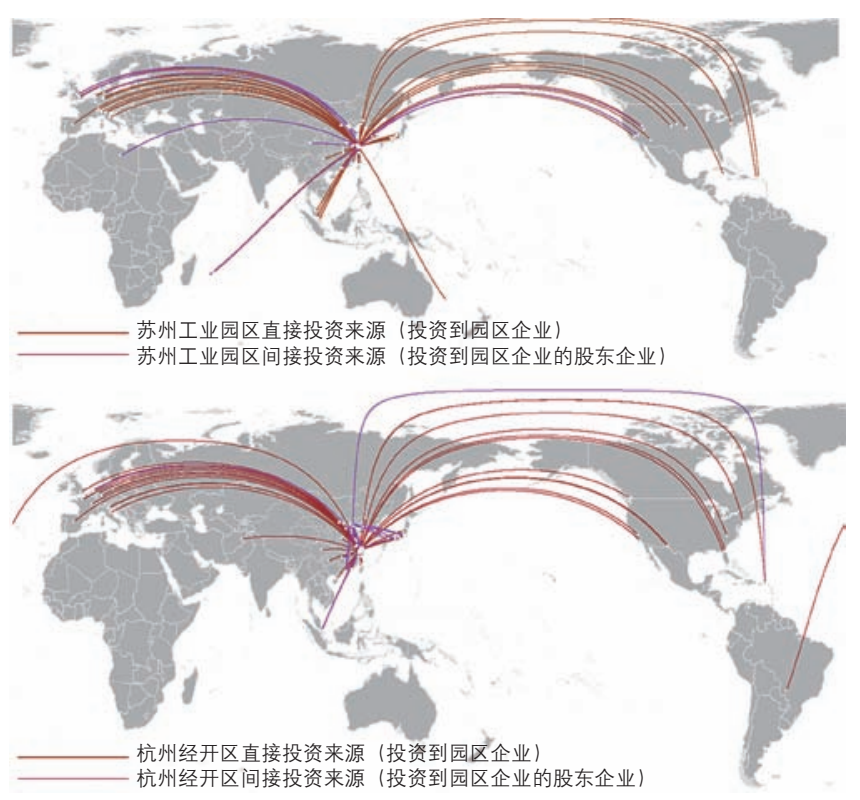

图 5 苏州工业园和杭州经开区规上工业企业投资来源对比图 资料来源 : 作者根据企业公司注册信息整理绘制

（1) 江苏省人民政府．江苏省外经贸发展纲要（2009-2012）. 2009.8.18.

(2) 南京市人民政府办公厅.南京市 “十三五” 开放型经济发展规划. 2017.1.4. 


\section{4 面向全球化的中国开发区规划创新及其作用}

与开发区的创建同步, 中国的开发区规划实践也开始推 进。开发区的规划探索开始于中国法定城市规划体系初步成 型的 1980 年代初期, 发展和繁荣于中国法定城市规划体系 全面建立的 1990 年代之后, 不仅有效地支撑和适应了开发 区自身发展的需求，也为中国基于计划经济的城市规划体系 适应全球化和市场经济进行了探索。中国开发区规划体系 在建设之初以基于计划经济的城市（含独立工矿区）规划 为蓝本, 结合开发区独特的对外开放政策环境和外商投资、 外向型产业发展等全球化发展需求, 逐步形成了具有特色、 能够适应全球化和市场化的规划体系。与一般城市规划比 较, 面向全球化的中国开发区规划创新突出体现在以下几 个方面。

（1）规划体系。构建了全市统一性与开发区特殊性相结 合的规划体系, 并突出外向型产业发展和集聚的要求: 开发 区的规划体系经历了由相对独立于城市规划到统一性与自主 性相结合的变化过程。改革开放初期, 作为新生事物, 开发 区与城市空间完全独立，尝试构建独立的开发区规划编制与 管理体系，如 1986 年发布的《江苏省经济技术开发区管理 条例》明确开发区管委会的职责包括 “制定开发区的总体规 划和发展计划”。随着开发区与城市关系的密切和相互之间 出现越来越多的冲突, 开发区的规划逐步强调与城市规划的 统一性，同时突出其作为产业空间和特殊政策空间的特点, 逐步形成了总体规划层面与城市规划统一, 产业规划和具体 用地规划由开发区主导的规划体系。如《深圳经济特区高新 技术产业园区条例》（2001 年）确定市政府需要按照 “深圳 市城市总体规划, 根据高新区的发展需要和实际情况, 对 高新区和高新技术产业带的建设用地与发展进行统一规划”, 高新区行政管理机构 “组织编制高新区总体发展规划、产业

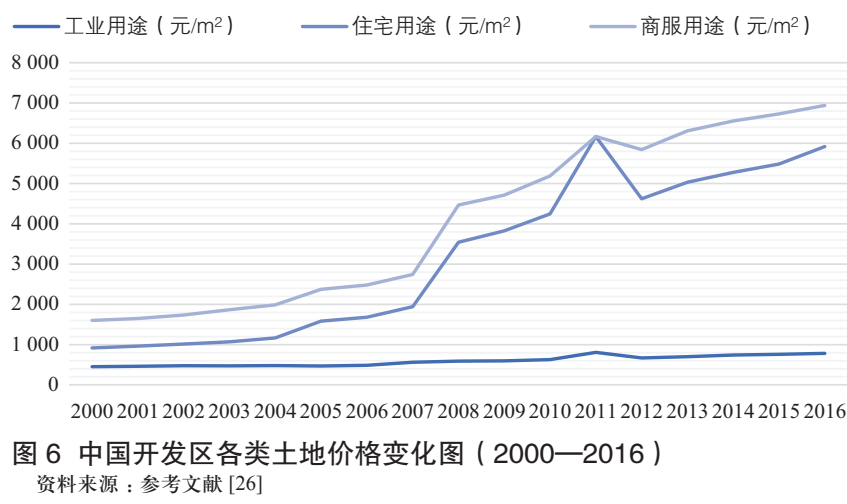

发展规划; 参与编制高新区分区规划以下层次的城市规划、 信息化建设规划和环境保护专项规划”。《宁波国家高新技术 产业开发区条例》(2009 年) 确定管委会的职能包括 : 制定 区域内科技、经济、社会发展规划, 经市人民政府批准后负 责组织实施; 受市规划行政部门的委托, 编制区域内的总体 规划, 负责编制区域内控制性详细规划和专业规划, 经批准 后组织实施。

（2）空间规划。在传统单纯的功能分区基础上, 考虑土 地市场化出让的需要, 进行标准化的地块划分和建设条件控 制: 在开发区总体规划层面, 考虑到土地出让的地块切分要 求和兼顾不同类型、规模企业用地需求的差异性, 一般在产 业地块规划以主干道一次干道两级路网形成方格网为主的基 本地块单元, 在控详阶段再依据项目需求进一步细化路网, 并明确地块的基本建设控制要求, 或者在项目规划设计阶段 再进行细化相关设计。随着开发区土地资源的逐步趋紧和集 约利用土地要求的提升, 在产业地块的出让条件中逐步探索 加上了对产业准人的相关控制要求, 与一般城市空间的控制 性详细规划逐步区别开来。

（3）支撑系统。综合营商环境和服务体系的规划建设： 早在 1984 年国务院批转的《沿海部分城市座谈会纪要》中, 就明确提出 “十四个城市及其要兴办的经济技术开发区, 都 要加强基础设施建设, 为吸引外商投资提供必要的物质条 件”。为了更好地吸引全球投资和人才, 开发区规划均比较 重视对接国际最前沿的规划建设理念, 建设符合国际化水 准和需求的综合营商环境。同时面对国际投资的需要, 规 划高效率、符合国际惯例的生产服务体系、行政管理体系 和生活配套服务体系, 比如规划建设国际社区、国际学校、 教堂等, 满足国际人才的生活需求。如苏州工业园区规划 建设有韩国人社区和韩语学校、外国语学校等等; 西安高 新区则专门成立国际社区开发的公司, 并规划建设国际社 区来反向带动全球人才和要素的集聚。按照规划设想, 西安 国际社区是顺应西安建设国际化大都市和西安高新区创建国 家自主创新示范区战略, 以改善区域生态、人居环境, 促进 人文、科技、商务交流为目的, 完善区域国际化城市服务功 能, 以提升西安高新区国际化产业配套水平为目标的现代化 城市功能新区 ${ }^{(1)}$ 。

（4）规划实施管理。开发区规划管理既要保持与所在城 市规划管理的一致性, 又要考虑外向型产业开发项目的特殊 性和灵活性, 所以基本实行了与城市规划管理统分结合的管 理实施体系。在国家层面, 对开发区的规划管理走过了一个 由放到收的过程。1995 年原国家建设部颁布的《开发区规划

(1) 西安国际社区网站: http://www.xaic.org/list-5-1.html。 
管理办法》中赋子了开发区独立设置规划管理部门和开展规 划编制与实施管理的权力, 2003 年 9 月 2 日发布的《关于进 一步加强与规范各类开发区规划建设管理的通知》则明确: 城市规划区内及其边缘地带的各类开发区的规划建设, 必须 纳人城市的统一规划和管理, 各类开发区已设立的规划管理 机构, 都应作为所在城市城乡规划行政主管部门的派出机构, 行使委托的建设项目建议权和规划实施监督检查权。2008年, 《中华人民共和国城乡规划法》则在城市空间布局上进一步 明确 “在城市总体规划、镇总体规划确定的建设用地范围以 外，不得设立各类开发区和城市新区”。在国家强调开发区 与城市规划的统一性和开发区本身必须要应对的全球化投资 的灵活性之间, 在各地的开发区规划管理实践中, 多数采取 了按照限额由城市规划管理部门委托授权开发区规划管理部 门进行规划实施管理的模式。例如南京市 2012 年对国家级 开发区的规划管理授权曾经规定开发区管委会负责 “区域工 业、市政基础设施及专为工业生产配套的公共设施等建设项 目的《建设项目选址意见书》《建设用地规划许可证》《建设 工程规划许可证》的核发, 受委托核发《建设工程规划许可 证》项目的建设工程验线、规划条件核实, 以及负责建设项 目的监督检查” (1)。这种授权确保了开发区应对国际投资的 规划管理和服务能够及时和精准。

\section{5 结语与展望}

本文系统梳理了中国开发区与全球化之间的互动关系, 总结了其互动的内在机制, 并对开发区应对全球化过程中开 发区规划的创新进行了简要分析。研究认为, 中国开发区是 顺应全球化的产物, 开发区的发展与全球化之间在不同阶段 均具有密切的内在联系, 全球化与开发区的互动机制, 可以 概括为三个方面的作用和效应, 包括政策激励机制、要素纽 带机制以及比较优势形成的集聚机制。为了更好地适应全球 化发展, 开发区规划在规划体系和产业规划、空间规划、支 撑系统规划等方面进行了创新, 有效地支撑了开发区的全球 化发展。

全球化正在进人新的时代, 一个以 “互联互通” 为主要 标志, 包括地理互联、经济互联和数字互联等为内涵的所谓

“超全球化” 时代已经来临 ${ }^{[25]}$, 中国的 “一带一路” 倡议 成为塑造新的全球化格局的重要驱动力量。就中国与全球 化的关系而言, 已经迈过了单向的资本输人和商品输出的 低层次 “世界工厂”阶段, 而迈人中国资本、中国建造和 中国制造以及中国技术等的综合输出, 以及国际高层次技 术、人才输人相辅相成的新阶段。中国开发区在新全球化
中的作用也在改变, 正在成为中国深度融人新全球化的重 要平台, 中国开发区作为一种实现后发超越的有效工具和 发展模式, 受到全世界的重视和关注, 尤其是“一带一路” 沿线的广大发展中国家和地区, 大力引进中国开发区模式, 通过与中国合作建设等途径, 建立本土工业化的基地和平 台。在这样的背景下, 中国开发区依然成为重塑全球新型工 业体系的重要力量, 必将发挥引领全球工业化的重要作用。 系统总结和梳理中国开发区的发展、规划和建设经验, 形成 可推广、可复制的理论行业技术成果，对支撑 “一带一路” 倡议和促进其他国家分享中国开发区经验、实现共同繁荣， 具有重要的战略价值。UPI

研究生谢亚协助进行了企业网络分析, 在此予以感谢。

\section{参考文献}

[1] PARK J D. The Special Economic Zones of China and their impacts on its economic development[M]. Greenwood Publishing Group, 1997.

[2] GE W. Special Economic Zones and the economic transition in China[M]. World Scientific, 1999: 109-139.

[3] WANG J. The economic impact of Special Economic Zones: evidence from Chinese municipalities[J]. Journal of Development Economics, 2013, 101(1): 133-147.

[4] WU B S, SUI D. Modeling impacts of globalization on desakota regions: a case study of Taipei Metropolitan Area[J]. Environment \& Planning B Planning \& Design, 2016, 43(2): 3391-3392.

[5] GE W. Special Economic Zones and the opening of the Chinese economy: some lessons for Economic Liberalization[J]. World Development, 1999 , 27(7): 1267-1285.

[6] KLEIN O, PACHURA P, TAMASY C. Globalizing production networks[J]. Polish Journal of Management Studies, 2016, 13(2): 81-89.

[7] 周伟林, 周雨萧, 柯淑强、基于开发区形成、发展、转型内在逻辑的 综述 [J]. 城市发展研究, 2017, 24(1): 9-17.

[8] 宋迎昌. 中国沿海地区外向型经济发展的国际背景分析 [J]. 地理学报, 1996(3): 193-201.

[9] 吴莉娅, 顾朝林. 全球化、外资与发展中国家城市化一一江苏个案研 究 [J]. 城市规划, 2005(7): 28-33.

[10] 陈益升, 湛学勇.中国两类开发区: 比较研究 (连载) [J]. 中国科技产业, 2002(7): 54-56.

[11] 郑静, 薛德升, 朱泣. 论城市开发区的发展：历史进程、理论背景及 生命周期 [J]. 世界地理研究, 2000(2): 79-86.

[12] 顾朝林, 陈果, 黄朝永, 等。论深圳新工业空间开拓一一经济全球化、 产业结构重建与转移的结果 [J]. 经济地理, 2001, 21(3): 261-265.

[13] 郑国, 张延吉. 基于要素演替的国家级开发区转型研究 [J]. 经济地理, 2014, 34(12): 114-118.

[14] 程慧, 刘玉亭. 国家级经济技术开发区的转型路径与机制解析 [J]. 规划 师, 2017, 33(7): 112-118.

[15] 熊军, 胡涛. 开发区 “二次创业” 的全球化视角一一对长江三角洲 开发区“二次创业”的分析 $[J]$. 华中师范大学学报(自然科学版) , 2001(4): 489-492.

[16] 黄健, 徐山瀑, 沈和. 走向经济全球化的成功典范——苏州工业园区 十年发展鸟瞰 [J]. 现代经济探讨, 2005(6): 17-20.

(下转 32 页)

(1) 南京市规划局.市规划局关于将规划行政事项委托给有关区政府、园区行使的通知 [ 宁规字 [2012] 303 号], 2012. 
展条件及双边合作领域、合作深度对园区进行理性定位, 避免盲目跟风; 根据自身产业基础及合作国家产业优势 找准园区特色, 明确产业发展方向, 避免产业同构, 恶 性竞争。

（3）内外兼修, 多元发展。国际合作园区发展受国际关 系、国家外交政策影响极大, 应建立风险评估及预警机制, 预留风险应对措施。充分利用国内国外两种市场、两种资源, 坚持区域协调、内外联动、面向全球、互利共赢的发展方针, 建立双向深层开放与互融的开放发展新机制。UP

\section{参考文献}

[1] 梁曙霞, 刘舒亚, 祖强. 促进政府主导型中外合作园区创新发展 [J]. 唯 实, 2016(4): 51-54.

[2] 林泉礼, 王鲁志。迈向国际性开发与合作的一步——珲春边境经济合 作区总体规划 [J]. 城市规划, 1993(3): 37-40+62.

[3] 陈启宁. 苏州工业园区的城市规划 [J]. 规划师, 1999(2): 38-41.

[4] 施玉初, 杨晓敏, 莫栋升, 李盛, 借鉴与实践——苏州工业园区城市规 划建设及管理经验浅谈 [J]. 江苏城市规划, 2006(9): 6-11.

[5] PHELPS N A. Gaining from globalization? state extraterritoriality and domestic economic impacts - the case of Singapore[J]. Economic Geography, 2007, 83(4): 371-393.

[6] Han M. The China-Singapore Suzhou Industrial Park: can the Singapore model of development be exported? [J]. Masters, 2008.

[7] YU C, DIJKEMA G P J, DE JONG M, et al. From an eco-industrial park towards an eco-city: a case study in Suzhou, China[J]. Journal of Cleaner Production, 2015, 102: 264-274

[8]邹堂, 李晓宇. 国际合作园区发展特征与趋势研究 [J]. 中华建设, 2016(4): 74-75.

[9]王子昌. 新加坡发展模式的输出与借鉴: 苏州工业园案例研究 [J]. 东南 亚研究, 2011(5): 46-51.

[10] 刘雯. 国际合作园区的未来发展一一来自中德生态园的启示 [J]. 国际 经济合作, 2013(3): 42-45.

[11] 刘舒亚、浅析江苏中外合作园区的发展创新之路 [J]. 统计科学与实践, 2015(1): 37-40.

[12] 梁曙霞, 刘舒亚, 祖强. 促进政府主导型中外合作园区创新发展 [J]. 唯 实, 2016(4): 51-54.

[13] 王㭉, 王川.吉林省中俄农业合作园区建设的现状及意义 [J]. 贵州农业 科学, 2013(11): 229-233.

[14] 蔡苏文, 杨雯. 青岛市加快建设中韩合作园区的对策 [J]. 环渤海经济瞭 望, 2016(8): 33-35.

\section{( 上接 22 页)}

[17] 朱仲羽。经济国际化进程与经济性特区功能形态的演变：兼论中国开 发区的转型取向 [J]. 世界经济, 2001(12): 69-72.

[18] 张晓平。跨国公司在开发区的投资模式及区域影响 [J]. 地理研究, 2005, 24(4): 631-640.

[19] 袁晓玲, 杨万平, 胡德佳. FDI 与区域经济增长——基于西安高新技术 产业开发区数据的计量检验 [J]. 城市发展研究, 2007, 14(5): 119-122.

[20] 杨东峰, 熊国平, 王静文. 沿海开发区一种典型深层结构: 天津泰达 为例一一全球链接 - 区域独立・自身极化 [J]. 城市规划, 2007, 31(7): 25-31.

[21]朱卫东, 陈劲松, 张先锋、转型条件下新升级国家级开发区发展研究: 背景、障碍与策略 [J]. 经济问题探索, 2013(5): 108-114.

[22] 艾少伟, 苗长虹。异质性“通道”与跨国公司地方化结网一以苏州 工业园为例 [J]. 地理研究, 2011, 30(8): 1483-1498.

[23] 孙暟泽, 西宝, 李清均. 中国开发区发展转型问题研究 [J]. 学习与探索, 2015(10): 109-113.

[24] 王兴平, 顾惠。我国开发区规划 30 年一一面向全球化、市场化的城乡 规划探索 [J]. 规划师, 2015, 31(2): 84-89.

[25] 帕拉格 - 康纳. 超级板图: 全球供应链、超级城市与新商业文明的崛 起 [M]. 崔传刚, 周大昕, 译. 北京: 中信出版社, 2016:38.

[26] 顾惠.中国开发区营商成本变化特征及其空间影响研究——江苏省 为例 [D]. 南京: 东南大学, 2017 .

(本文编辑：王枫)

(本文编辑：许玫) 